Images in ...

\title{
Temporal abscess after tooth extractions
}

\author{
Sigbjørn Løes, Njål Lekven
}

Department of Maxillofacial Surgery, Haukeland University Hospital, Bergen, Norway

Correspondence to Sigbjørn Løes, sigbjorn.loes@odont.uib.no

\section{DESCRIPTION}

A 34-year-old man with diabetes mellitus, but otherwise healthy and with no previous record of drug addiction, had two molars of the upper jaw removed. Three days later he developed a swelling and redness in his left temple and periorbital region. He was tender to palpation and not able to open his left eye (figure 1). His general condition was good with no fever, but $C$ reactive protein was 301 when he was admitted to hospital 7 days after surgery. MRI scan showed an abscess located lateral to the alveolar crista of the upper jaw and upwards deep to the temporal fascia (figure 2). Eye functioning was unaffected and the MRI scan did not show any orbital involvement. The abscess was drained through a temporal incision, with excellent clinical and laboratory response. Microbiological samples showed Streptococcus milleri and Prevotella species, typical for an odontogenic abscess.

Even before admission to hospital he was treated with penicillin and metronidazole. Pending microbiological analyses, penicillin was substituted with cefotaxime for a short time.

Odontogenic infections may easily spread along muscles and fasciae, ${ }^{1}$ and may also cause parapharyngeal abscesses or pus accumulation deep to the cervical fasciae as, for example, Ludwig's oangina.

They can enter the masticatory

space, ${ }^{2}$ but rarely invade tissue superior to this, as in this case. In this location, the origin of the abscess may be

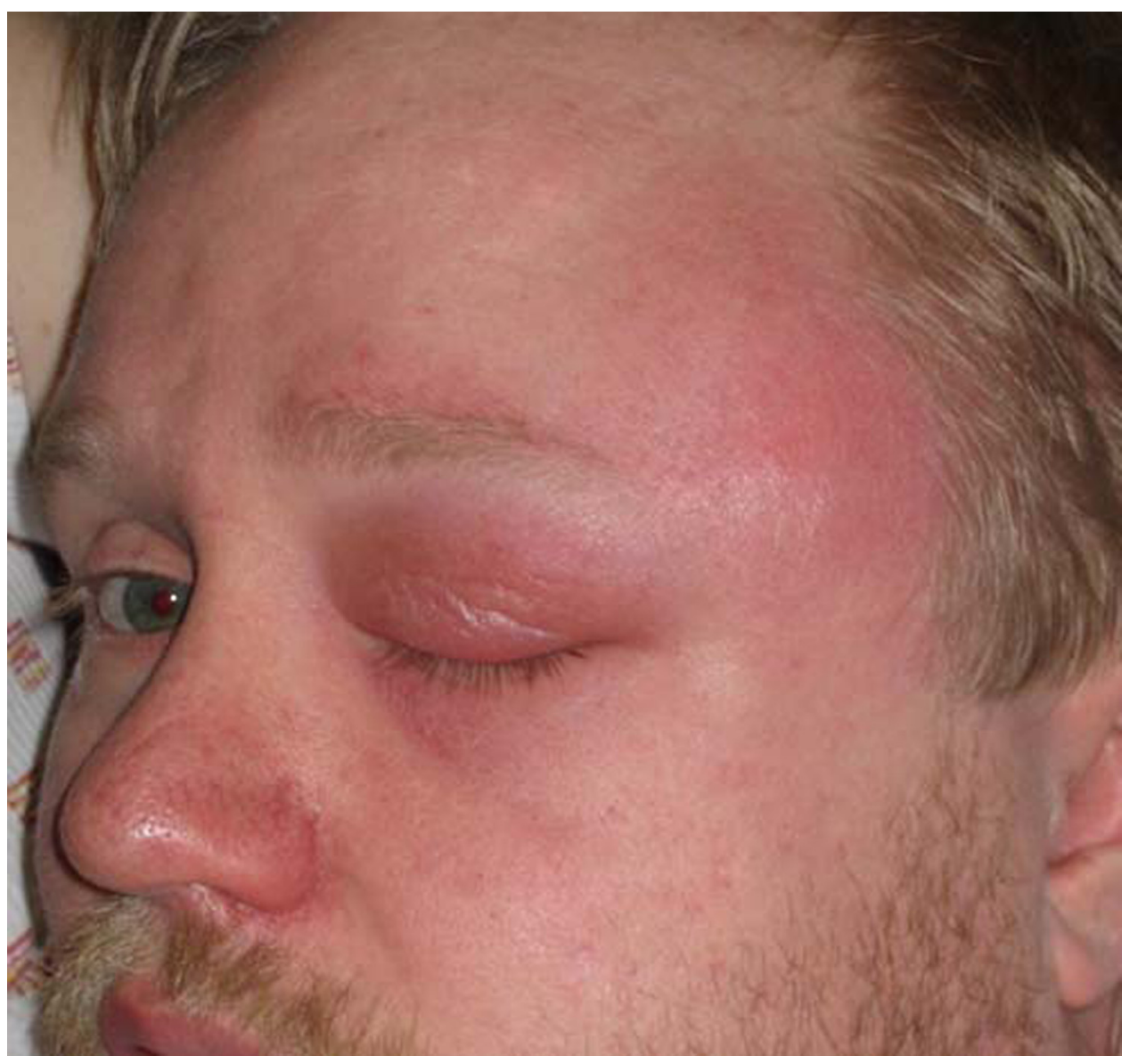

Figure 1 Redness and swelling periorbital and in the temple region. Only minor trismus and very modest symptoms from the jaw and oral cavity. 


\section{BMJ Case Reports}

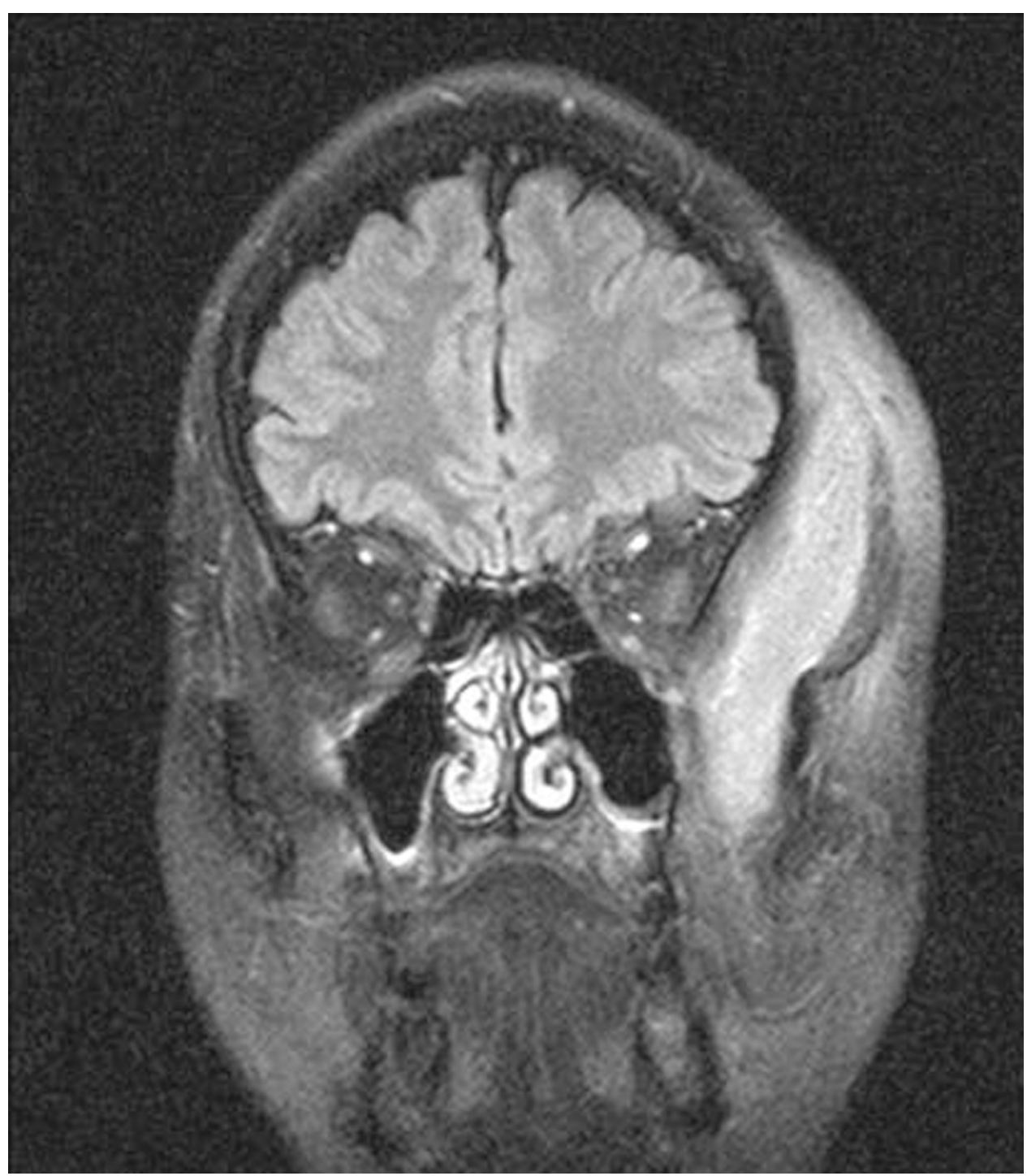

Figure 2 MRI scan showing an elongated abscess probably originating from the left side alveolar crista occupying a large space deep to the temporal fascia.

difficult to reveal. It may cause risk of thrombosis of the cavernous sinus and even jeopardise the orbit. ${ }^{3}$ Surgical drainage, elimination of infection focus, antibiotics and antithrombotic drugs is the treatment of choice.

Competing interests None

Patient consent Obtained.

\section{REFERENCES}

1. Schuknecht B, Stergiou G, Graetz K. Masticator space abscess derived from odontogenic infection: imaging manifestation and pathways of extension depicted by CT and MR in 30 patients. Eur Radiol 2008;18:1972-9.

2. Akst LM, Albani BJ, Strome M. Subacute infratemporal fossa cellulitis with subsequent abscess formation in an immunocompromised patient. Am J Otolaryngol 2005;26:35-8.

3. Kim IK, Kim JR, Jang KS, et al. Orbital abscess from an odontogenic infection. Oral Surg Oral Med Oral Pathol Oral Radiol Endod 2007;103:e1-6. 


\section{BMJ Case Reports}

This pdf has been created automatically from the final edited text and images.

Copyright 2010 BMJ Publishing Group. All rights reserved. For permission to reuse any of this content visit

http://group.bmj.com/group/rights-licensing/permissions.

BMJ Case Report Fellows may re-use this article for personal use and teaching without any further permission.

Please cite this article as follows (you will need to access the article online to obtain the date of publication).

Løes S, Lekven N. Temporal abscess after tooth extractions. BMJ Case Reports 2010;10.1136/bcr.01.2010.2656, date of publication

Become a Fellow of BMJ Case Reports today and you can:

- Submit as many cases as you like

Enjoy fast sympathetic peer review and rapid publication of accepted articles

- Access all the published articles

- Re-use any of the published material for personal use and teaching without further permission

For information on Institutional Fellowships contact consortiasales@bmjgroup.com

Visit casereports.bmj.com for more articles like this and to become a Fellow 